\title{
Energy audit: A case study to reduce lighting cost for an industrial site
}

\author{
O. Dzobo ${ }^{1}$, H. Tazvinga ${ }^{2}$, E. Mungofa ${ }^{3}$, C. H. Chihobo ${ }^{3}$, F. Chikuni ${ }^{4}$, and E. \\ Chikuni $^{5}$ \\ \{ odzobo@yahoo.com, htazvinga@csir.co.za, mungofaemma@gmail.com\} \\ ${ }^{1}$ University of Johannesburg, Dep. of Electr. \& Electronic Eng. Sci., Johannesburg, \\ South Africa, \\ ${ }^{2}$ Energy Centre, Council for Scientific \& Industrial Research, Pretoria, South Africa \\ ${ }^{3}$ Chinhoyi University of Technology, Dep. of Fuels \& Energy, Chinhoyi, Zimbabwe
}

\begin{abstract}
Lighting is an essential service in all industries. Recent innovation and continuous improvement in the field of lighting has given rise to tremendous energy saving opportunities in this area. This paper presents the results of an energy audit carried out at an industrial site of a famous manufacturing/mining holding in Zimbabwe. It has been demonstrated in this specifc case study that the improvement of lighting technologies can determine a reduction of electricity consumption more than 150 $000 \mathrm{kWh} /$ year with an annual electricity cost saving of the order above $\$ 50000$ per year. The total simple payback time of the proposed lighting retrofitting is evaluated to be less than 2 years on average.
\end{abstract}

Keywords: Energy audit, energy saving, lighting, energy efficiency.

\section{Introduction}

Lighting continues to be the largest electrical end-use service offered by power utilities worldwide. In 2005, grid-based electric lighting consumed about 2 651Tera Watt hour (TWh) of electricity, accounting for $19 \%$ of the global electricity consumption [1]. The recent advances in lighting technologies has given rise to tremendous energy saving opportunities of lighting energy use [2]. Research studies have shown that great savings can be achieved through energy efficiency solutions of lighting retrofit [2], [3], [4], [5], [6]. It is therefore important to carry out continuous energy audit and process tracking of industrial lighting electricity consumption to ensure sustainable and energy efficient manufacturing and processing plants.

Energy efficiency lighting projects can be implemented by either reducing input wattages or reducing the utilisation hours of the lights [7], [8], [9]. These energy saving measures are widely implemented in residential, commercial and industrial sectors around the world [3], [5], [6], [7]. For example, a large number of lighting energy saving projects have been implemented under various incentive Energy Efficiency (EE) programmes such as clean development mechanism (CDM) [8], white tradable certificate (WTC) scheme [9], demand side management (DSM) programmes [7], [10], and performance contracting [11]. In Zimbabwe, an energy efficiency drive that was launched by Zimbabwe Energy Regulatory Authority (ZERA) in 2012, where people were encouraged to replace incandescent light bulbs

ACRID 2017, June 20-21, Victoria Falls, Zimbabwe

Copyright (C) 2017

DOI 10.4108/eai.20-6-2017.2270760 
with fluorescent light bulbs, resulted in a significant energy saving to the country [12]. These energy efficiency programmes help to reduce the strain on the scarce electrical energy resources and production cost of electricity. In this paper, a case study to reduce lighting energy consumption cost at an industrial site is carried out. The case study is a mining company that employ shallow underground mining; currently mining at a depth of circa $200 \mathrm{~m}$ and processes ore through a single facility utilizing a combination of crushing, conventional sag milling, combined gravity and the Carbon In Leach (CIL) process, electro-winning and bullion smelting. The following section outlines the stages that were carried out during the energy audit of the industrial site.

\section{Energy Audit}

Energy audit is the implementation of energy saving opportunities through blending technically feasible solutions with economic and other organizational considerations within a given period of time [5]. It identifies how and where energy is used and propose methods for energy savings. The scope of an energy audit, the complexity of analyses, and the level of economic evaluation are parameters that may be considered differently by each individual auditor and should be defined prior to the beginning of any energy audit activities [5].

In order to carry out an energy audit and implement its recommendation, the company top management must be convinced of the necessity of implementing energy management at their company [10], [11]. The methodology adopted for this energy audit is a three step process of:

1. Data Collection: In data collection phase, exhaustive data collection was performed using different tools such as observation, interviewing key persons, and measurements were done using lux meter.

2. Data Analysis: Detailed analysis of collected data was done from the database that was generated. This forms the baseline case which is used later to quantify any energy cost savings achieved as a result of recommended and implemented energy efficiency interventions.

3. Recommendation: On the basis of results from the detailed data analysis and observations, some steps for reducing lighting energy consumption without affecting the comfort and satisfaction of employees were recommended along with their cost analysis.

\section{Lighting Assessment}

A walk-through audit was conducted during visits to the industrial site. The main objective of the walk-through energy audit was to assess the illumination requirement of the plant and scope of improvement of illumination quality and level. Consequently, finding ways to reduce the lighting electricity consumption and thus reducing the cost of electricity of the industrial processing plant.

The light levels in the plant and selected offices were measured during day time by using a lux/light meter. Measurements were taken at a number of points and averaged. For offices the light levels were also determined with the lights OFF and window-blinds fully open. The measured light levels were compared with the Zimbabwean Lighting Standard (Factories Act 
section 5 of GRN No. 262 of 1976, Zimbabwe). Qualitative data was gathered using unstructured interviews with plant personnel.

\section{Current practise and Observations}

It was noted that presently, reflectors on lighting fixtures are removed resulting into wastage of light towards ceiling. Generally, the current lighting levels of the plant and offices meets the recommended standards and safety requirements of the Zimbabwe Lighting Standards. Table 1 below shows a comparison of the lighting levels that were measured and the Zimbabwe Lighting Standards lighting levels. The predominant color of room walls (offices) is white and this color is more preferred because of its good reflective coefficient.

Table 1. Comparison of current lighting levels with different lighting standards.

\begin{tabular}{llllll}
\hline Section Area & $\begin{array}{l}\text { Average } \\
\text { Measured } \\
\text { Lux Levels }\end{array}$ & $\begin{array}{l}\text { SANS 10114-1 } \\
\text { Recom. [13] }\end{array}$ & $\begin{array}{l}\text { ZIM Legis- } \\
\text { lated }\end{array}$ & $\begin{array}{l}\text { Meets } \\
\text { Recommended } \\
\text { Std. }\end{array}$ & $\begin{array}{l}\text { Meets } \\
\text { Safety } \\
\text { Req. }\end{array}$ \\
\hline Stores & 212 & 400 & 200 & Yes & Yes \\
General Offices & 202 & 400 & 200 & Yes & Yes \\
Process Offices & 202 & 400 & 200 & Yes & Yes \\
Compressor House & 444 & 400 & 200 & Yes & Yes \\
Boardroom & 287 & 500 & 200 & Yes & Yes \\
Reception Desk & 466 & 300 & 200 & Yes & Yes \\
$\begin{array}{l}\text { Engineering } \\
\text { Workshop }\end{array}$ & 496 & 400 & 200 & Yes & Yes \\
\hline
\end{tabular}

The plant is currently illuminated using a mixture of high efficiency and standard lighting. Almost $100 \%$ of lighting throughout the office buildings is fluorescent lighting. The most common were the T8/58W tubular type and T12/36W tubular type. These lights are currently in use 8760 hours per year, assuming that all lights are ON during plant shutdown period for cleaning and repairing. The office lights are assumed to be ON throughout the year since the industrial unit operates for 24 hours everyday. For outdoor lighting purposes the HPS/400W flood lights are used. The lighting method employed is direct lighting where 90 to $100 \%$ of the light is directed downward for maximum usage. It is also interesting to note that in the workshops, task lighting is employed and ambient lighting is provided by the sunlight. This is a commendable move as it can save a lot of electricity if employed on a larger scale. The predominant lighting controls at the industrial site are: single pole manual switch, time clocks and a few daylight photo cell switches.

The personnel at the industrial site are attempting to keep its operations as energy efficient as possible both in the short and long term. The management have recognised that the plant must show a profit to attract investment required for funding of energy saving initiative projects. A local energy committee is already set up and is required to come up with cost benefit analysis of proposed energy initiative projects in order for the project to be funded. This is very commendable as this would allow their products to be competitive through reducing electricity consumption costs. 


\section{Recommendations}

After the energy audit survey and detailed data analyses, the energy audit team put forward the following recommendations for the company to implement.

\subsection{Switching off lights}

Most of the outdoor flood lights were left $\mathrm{ON}$ during the day. In most cases it was because of the malfunctioning of the daylight photocell switches. Energy saving calculations were done for a single flood light assuming it is supposed to be OFF for 12 hours during the day. The calculations show that the company would save US\$614.40 per day per flood light by making sure that each flood light is switched OFF. The cost of one daylight photocell switch is approximately US\$350 which is far less than the daily cost saving of switching OFF one outdoor HPS/400W flood light.

\subsection{Utilization of daylight}

There is need for the responsible personnel to remind personnel or office occupants to switch OFF office lights and utilize daylight. This can be done by putting stickers at the doors of each office (see Fig. 1). This energy conservation strategy can save a lot of electricity as some employees even forget to switch OFF their office lights when they go home.
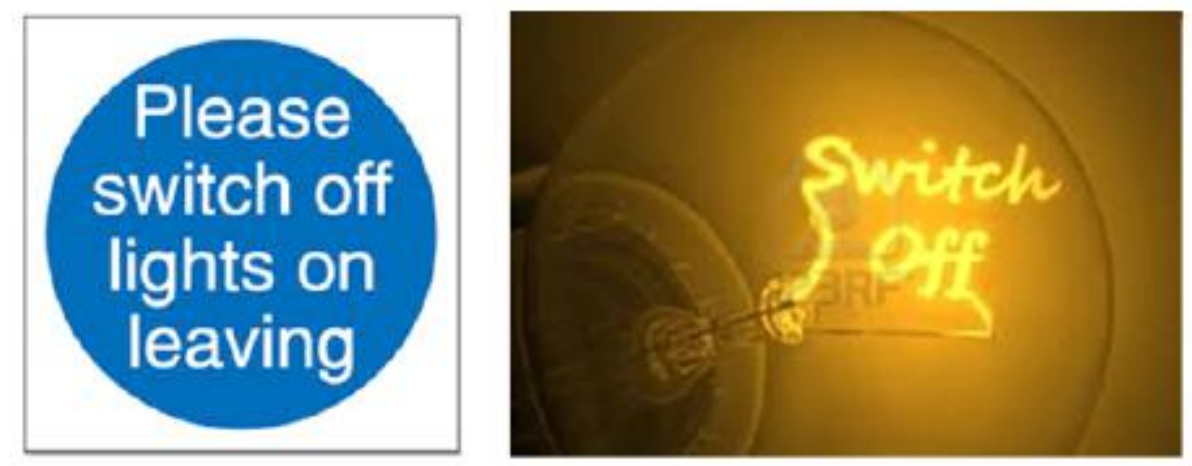

Fig. 1. Poster on doors of each office.

\subsection{Switching off lights}

Replacing T8 and T12 fluorescents with LEDs: The predominant type of lighting in the plant is the T8/5 foot/58W lamp. The recommended replacement for the T8/58W lamp are T8 LEDs which fit in exactly the same fixture and ballast hence there is no need to replace the fixtures. The lumen output of the LEDs is lower and it varies between 990-2350 lumens. It has a lifespan of over $50000 \mathrm{hrs}$ and excellent color rendition at over $80 \%$ color rendition index (CRI). To calculate the annual energy saving (AES) the following equation, Eq. (1), was used.

$$
A E S=(E W-P W)(N \times H R S \times C)
$$


where: AES - annual energy savings; EW - existing wattage; $P W$ - proposed wattage; $N$ number of fixtures; HRS - annual hours of operation and $C$ - conversion constant: $0.001 \mathrm{~kW} / \mathrm{W}$

The annual energy cost savings (AECS) is calculated from the following equation, Eq (2):

$$
\text { AECS }=\text { AES } x \text { MC }
$$

where: AECS - Annual energy cost saving and MC - Marginal cost of electricity: $\$ 0.128 / \mathrm{kWh}$

In addition to the annual energy savings, there is also an annual energy demand savings calculated from Eq (3) below:

$$
A E D S=(E W-P W)(N \times B M x M C)
$$

where: AEDS - Annual energy demand saving and BM - Billed months per year for demand, 12

Thus the annual demand cost savings is found using the following equation, Eq. (4):

$$
A D C S=A E D S x M C
$$

where: ADCS - Annual demand cost saving and MC - Marginal cost of demand: $\$ 4.07 / \mathrm{kVA}$

The net annual cost savings, NACS, can now be calculated using the following equation, Eq. (5):

$$
\text { NACS }=\text { AECS } x \text { ADCSC }
$$

Table 2 below shows the energy cost saving of replacing T8/58W lamp with T8 LEDs.

Table 2. Electricity cost saving for replacing T8/T12 with LED.

\begin{tabular}{llllll}
\hline Description & T8 & T12 & LED & Saving & $\begin{array}{l}\text { Operating } \\
\text { Hours }\end{array}$ \\
\hline Fixture & & & & & 8760 \\
Consumption (W) & & $36 / 18$ & $20 / 15 / 8$ & - & \\
Consumption kWh & 181384.56 & 21129.12 & 71350.20 & 131163.48 & 8760 \\
$\begin{array}{l}\text { Consumption Costs } \\
\text { @ } 12.8 \text { cents }\end{array}$ & US 23217.22 & US $\$ 2704.53$ & US\$9 132.83 & US\$16 788.93 & 8760 \\
\hline
\end{tabular}

The cost of implementing this recommendation will include the cost of purchasing the 20W LED light bulbs. Additionally, there will be cost of installing the new LED bulbs, and also the disposal costs for the current bulbs. Based on quotations provided from the company database, the 20W LED bulbs will cost approximately $\$ 50$ each. In this paper we assumed that the electrical department is responsible for installing the new LED bulbs at a cost of US $\$ 2$ per LED bulb. For the purpose of this calculation, based on the worst case scenario - no government rebates were considered.

Replacing HPS lights with LEDs: The plant uses 400W high pressure sodium (HPS) lighting for high bay lighting and outdoor applications. A total of about 130 are used for outdoor application. The recommended replacement is the newly designed E40, 80W LED bulb. It is a good replacement with a color coordinated temperature (CCT) of between 30006500 and excellent color rendition with a CRI of 85. It has an average life of 50000 hours 
which is double the lifespan of the HPS/400W :12000 24000 hour life. Assuming the flood lights are used between $6 \mathrm{pm}$ and $6 \mathrm{am}$ only, the energy cost saving results are presented in the Table 3 below.

Table 3. Electricity cost saving for replacing HPS with LED.

\begin{tabular}{|c|c|c|c|c|c|}
\hline Description & HPS & LED & Saving & $\begin{array}{l}\text { No. of } \\
\text { Fixtures }\end{array}$ & $\begin{array}{l}\text { Operating } \\
\text { Hours }\end{array}$ \\
\hline Fixture Consumption (W) & 400 & 80 & 320 & 130 & 4380 \\
\hline Consumption kWh & 227760 & 45552 & 182208 & 130 & 4380 \\
\hline $\begin{array}{l}\text { Consumption Costs } \\
\text { @ } 12.8 \text { cents }\end{array}$ & US\$29 154.28 & US\$5 830.66 & US\$23 322.63 & 130 & 4380 \\
\hline
\end{tabular}

The simple payback period can now be calculated as in Eq. 6 :

$$
\text { Simple payback period }=\frac{\text { Implementation } \text { Cost }}{\text { Net Annual cost saving }}
$$

The following Table 4 shows the simple payback for the recommended energy saving method.

Table 4. Simple Payback Period (SPP) results.

\begin{tabular}{lllllllll}
\hline Existing type & $\begin{array}{l}\text { Recommende } \\
\text { d Actions }\end{array}$ & $\begin{array}{l}\text { No. } \begin{array}{r}\text { of } \\
\text { replaced } \\
\text { bulbs }\end{array} \\
\end{array}$ & $\begin{array}{l}\text { Fixtures } \\
\text { changed }\end{array}$ & $\begin{array}{l}\text { AES } \\
\text { (kWh) }\end{array}$ & $\begin{array}{l}\text { ADS } \\
\text { (kVA) }\end{array}$ & $\begin{array}{l}\text { ACS } \\
\text { (US/year) }\end{array}$ & $\begin{array}{l}\text { Implem. } \\
\text { Cost } \mathbf{( \$ )}\end{array}$ & $\begin{array}{l}\text { SPP } \\
\text { (year) }\end{array}$ \\
\hline 400W HPS & bulb 80W LED & 130 & 130 & 364416 & 499.2 & 48677.0 & 37700 & 0.77 \\
58W T8 Flu. bulb & 20W T8 LED & 357 & 0 & 158784 & 217.5 & 21209.3 & 24804 & 1.20 \\
36W T8 Flu. bulb & 15W T8 LED & 54 & 0 & 9934 & 55.40 & 1496.5 & 2268 & 1.50 \\
18W T8 Flu. bulb & 8W T8 LED & 13 & 0 & 1139 & 1.60 & 152.30 & 351 & 2.30 \\
TOTAL & & & & $\mathbf{5 3 4 2 7 3}$ & $\mathbf{7 7 3 . 7 0}$ & $\mathbf{7 1 ~ 5 3 5 . 1 0}$ & $\mathbf{6 5 1 2 3}$ & $\mathbf{0 . 9 1}$ \\
\hline
\end{tabular}

\section{General recommendations}

- The engineering department should put in place a lighting inventory as part of the energy management program. The lighting inventory will document the failure rates of lamps, ballasts and the actual life expectancy levels, etc. This would help the company to track the number of energy saving opportunities implemented and their energy cost saving.

- Awareness training of personnel is also recommended on use of daylight and switching OFF lights when not in use. In some cases the HPS outdoor flood lights were left $\mathrm{ON}$ in some places where natural daylight was adequate.

The government should make it mandatory for every industrial site in the country to carry out energy audit. This would give every industry an opportunity to identify energy saving opportunities that can be implemented. If these energy saving opportunities are implemented it 
means a reduction in the production cost of their products and thus making their products competitive on the market.

In some cases, it is possible for the government to give incentives to companies that have implemented energy saving technologies. This would help to reduce the initial capital required to buy the replacement products. For example, in South Africa, the government through the Department of Energy and the power utility they provide rebates for companies that are implementing energy saving products. They also encourage competition among the industries by providing prizes for the most energy saving company during the year.

Companies can also be encouraged to use self fund energy saving project method. This means that, all the proposed energy saving initiative projects must be able to save some costs and the saving from one energy initiative project can be used to fund another energy saving initiative project. It is also possible to encourage companies to install energy efficient LED lamps after the current lamps are burnt out.

There is need to have formal trainings on energy issues (such as expert level trainings) in addition to the current awareness trainings done by the companies. It is important to involve both senior managers and lower level employees in the processes to identify the steps needed to fully implement the energy management elements at organizational facilities. Getting as wide a spread of people as possible, gives an idea as to how energy management is perceived throughout the organization.

\section{Conclusion}

The data analyses provided in this paper demonstrate that the improvement of lighting technologies can reduce electricity consumption by more than $150000 \mathrm{kWh} / \mathrm{year}$ with an annual electricity cost saving of the order above US\$50 000 per year. It is evident that the studied industrial site can save electricity by incorporating some changes in the lighting installation and making it energy efficient. Based on the results of this work,, it is clear that the reduction in electricity consumption if done at a larger scale will reduce the strain on the scarce electricity resources and the electricity production cost.

Acknowledgements: The authors would like thank ZERA, TENDER No. ZERA INF 03/2013 and Chinhoyi University of Technology, for providing the research funds for this project.

\section{References}

[1] International Energy Agency: Light's Labours' Lost-Policies for Energy-efficient Lighting. Paris: OECD/IEA, (2006)

[2] Mills, E.: Global lighting energy savings potential. Light \& Engineering, 10, pp 5-10, (2002)

[3] Gordic, B., Jovicic, S., Koucalovic, J.: Development of Energy management system - Case study of Serbian car manufacturer. Energy Conversion and Management Vol. 51, (2010)

[4] Fritz, W.L.O., Kahn M.T.E.: Energy Efficient Lighting System. Journal of Energy, vol.17 No. 4 (2006)

[5] Mendis N.N.R, Perera N.: Energy Audit: A case Study. Information and automation, ICIE 2006. IEEE International Conference, pp 45-50, (2006)

[6] Mahlia, T., Said, M., Masjuki, H., Tamjis, M.: Cost-benefit analysis and emission reduction of lighting retrofits in residential sector. Energy and Buildings, 37, pp 573- 578, (2005).

[7] Eskom: The measurement and verification guideline for demandside management projects. Technical Report, (2011) 
[8] Michaelowa, A., Jotzo, F.: Transaction costs, institutional rigidities and the size of the clean development mechanism. Energy Policy, 33, pp 511-523, (2005).

[9] Mundaca, L.: Transaction costs of Tradable White Certificate schemes: The energy efficiency commitment as case study. Energy Policy,35, 4340-4354, (2007).

[9] Botha-Moorlach, M., Mckuur, G.: A report on the factors that influence the demand and energy savings for Compact Fluorescent Lamp door-to-door rollouts in South Africa. Technical report, Eskom,(2009)

[10] Mozzo, M. A.: Measurement and verification of savings in performance, contracting. Energy Engineering, 96, pp 33-45, (1999)

[11] UNFCCC: NS-243 - Lighting system optimization by replacing incandescent and other lights with energy efficient LED lights, Application page, Technical Report,2017

[12] South African National Standard (SANS): Interior lighting Part 1: Artificial lighting of interiors, Technical document, (2005) 